\title{
The Earnings Effects of Multilateral Trade Liberalization: Implications for Poverty
}

\author{
Thomas W. Hertel, Maros Ivanic, Paul V. Preckel, and John A. L. Cranfield
}

\begin{abstract}
Most researchers examining poverty and multilateral trade liberalization have had to examine average, or per capita effects, suggesting that if per capita real income rises, poverty will fall. This inference can be misleading. Combining results from a new international cross-section consumption analysis with earnings data from household surveys, this article analyzes the implications of multilateral trade liberalization for poverty in Indonesia. It finds that the aggregate reduction in Indonesia's national poverty headcount following global trade liberalization masks a more complex set of impacts across groups. In the short run the poverty headcount rises slightly for selfemployed agricultural households, as agricultural profits fail to keep up with increases in consumer prices. In the long run the poverty headcount falls for all earnings strata, as increased demand for unskilled workers lifts incomes for the formerly self-employed, some of whom move into the wage labor market. A decomposition of the poverty changes in Indonesia associated with different countries' trade policies finds that reform in other countries leads to a reduction in poverty in Indonesia but that liberalization of Indonesia's trade policies leads to an increase. The method used here can be readily extended to any of the other 13 countries in the sample.
\end{abstract}

Poverty reduction is an increasingly important consideration in the deliberations on multilateral trade liberalization, and it has been accorded an important position in the Doha Development Round of the World Trade Organization (WTO) negotiations. ${ }^{1}$ Globkom and the World Bank sponsored a conference in Stockholm in October 2000 aimed at assessing the state of the art in

Thomas W. Hertel and Paul V. Preckel are professors and Maros Ivanic is a graduate research assistant in the Department of Agricultural Economics at Purdue University; their e-mail addresses are hertel@purdue.edu, preckel@purdue.edu, and ivanicm@purdue.edu. John A. L. Cranfield is assistant professor in the Department of Agricultural Economics and Business at the University of Guelph; his e-mail address is jcranfie@uoguelph.ca. The authors acknowledge support from the Development Research Group at the World Bank. Specifically, they would like to thank Will Martin for championing this work and making the household surveys available. They would also like to thank seminar participants at the World Bank, Cornell University, the 2001 GeWisola conference in Braunshweig, the Globkom conference in Stockholm, and the Inter-American Development Bank conference on trade policy in the Americas, as well as François Bourguignon, L. Alan Winters, and three anonymous reviewers for valuable comments.

1. See also the survey by Winters (2000) and the handbook on trade liberalization and poverty by McCullogh and others (2001).

THE WORLD BANK ECONOMIC REVIEW, VOL. 18, NO. 2,

(C) The International Bank for Reconstruction and Development / THE WORLD BANK 2004; all rights reserved. doi:10.1093/wber/lhh039

18:205-236 
quantitative policy research on trade policy and poverty. It drew together economists working with household surveys (Levinsohn and others 1999; Case 1998; Friedman 2001; Ianchovichina and others 2000, 2002) and researchers using computable general equilibrium (CGE) models with a poverty focus (Devarajan and van der Mensbrugghe 2000; Harrison and others 2002b). ${ }^{2}$ Conference participants came to the realization that factor markets, so critical for determining the trade-poverty linkage, have been neglected in much of the poverty research (Harrison and others 2002b; Hertel and others 2000). The same point was emphasized in the path-breaking CGE-based work of Adelman and Robinson (1978) and in a recent overview by Decaluwé and others (1999). More recently, Bourguignon and others (2002) have more fully developed the role of labor markets in determining the impact of macroeconomic shocks on poverty.

One reason for the historic neglect of factor markets in much of the research on poverty stems from the preference for focusing on the expenditure side of household surveys, because of the greater reliability of spending data for measuring poverty (Lipton and Ravallion 1995). Although valuable for poverty measurement, this focus is inadequate for counterfactual analysis of policies and poverty, which require proper treatment of the earnings effects. The factor price effects of trade policy changes are often substantial, particularly for households that do not have diversified sources of income but rely on sector-specific factors. For this reason, it is important to stratify households, identifying those with specialized earnings patterns (see also Decaluwé and others 1999).

In the long run, an increase in returns to labor and capital employed in one sector will attract more resources to that sector, spreading the gains more widely. The Stolper-Samuelson theorem states that if the benefiting sector is relatively intensive in unskilled labor, a rise in the relative price of this sector's output will boost economywide unskilled wages over the long run, benefiting wage earners not directly employed in that sector. This distinction between the short- and longrun earnings impacts of trade liberalization is a central theme of this article.

The work presented at the Globkom-World Bank conference on trade policy and poverty and other recent work reveal another deficiency. ${ }^{3}$ Linking multilateral trade liberalization and poverty requires a multiregion approach. But the country specificity of household surveys and their inconsistency with the multiregion models used for trade policy analysis make such analysis difficult.

The simplest approach to assessing the poverty impacts of multilateral trade liberalization sidesteps this problem by focusing solely on the average or per capita effects of trade liberalization (see, for example, Cline 2004). Thus the entire income distribution is assumed to shift in parallel, based on the predicted change in per capita income. To the extent that this equiproportional shift in

2. Other good examples are offered by Löfren (1999) and Evans (2001).

3. See also the recent survey of studies on trade and poverty by Reimer (2002). 
income following trade liberalization is positive, it will likely lift some households above the poverty line, so the poverty rate is predicted to fall. Decaluwé and others (1999) extend this approach by identifying different household types (smallholder farmers, landless laborers) and evaluating the per capita income change for each stratum independently. However, they continue to assume a parallel shift in the income distribution for each stratum. The national per capita approach is unlikely to be satisfactory, particularly in the short run when returns to specific factors are differentially affected by trade liberalization. The Decaluwé and others (1999) approach works fairly well in the short run, but not in the long run, when differences in the composition of self-employed earnings across the income spectrum come into play.

Recently, studies have sought to map the price changes from a CGE model directly to the survey data, circumventing the need to aggregate households. Chen and Ravallion (2003) combine disaggregated household survey data with trade liberalization results from the Global Trade Analysis Project (GTAP) model of global trade. Thus, they are able to draw conclusions about the impacts of accession on individual household types and locations, which is very attractive from a policy point of view. However, the well-known inconsistencies between survey data and national accounts data (which the trade models use) frequently give rise to contradictory predictions for national per capita outcomes. One contribution of this article is to show how to reconcile per capita earnings and spending patterns between the two frameworks, enabling consistent predictions of national per capita impacts of trade liberalization by both the trade model and the survey-based microsimulation analysis.

The methodology developed here was designed explicitly for multiregion analysis. By capitalizing on a newly available methodology for estimating household spending patterns across both countries and income strata within countries, spending behavior can be summarized parsimoniously. This allows more attention to be focused on the earnings side of the problem, which is critical to the results. Although the treatment of factor markets is rudimentary compared with the recent work of Bourguignon and others (2002), it has the virtue of being operational across a wide range of countries and household surveys. This approach has been implemented for 14 countries and could readily be applied to many more countries where income surveys are available.

This article begins by examining the pattern of earnings specialization in the sample of developing countries. The systematic patterns that emerge motivate the subsequent stratification of households. The analytical framework for the study consists of a microsimulation model, built on the household survey data and used to assess impacts on individual households, and a global trade model, used to generate price changes. A key part of the research exercise involves modifying the trade model and adjusting the two databases to be mutually consistent and produce the same national per capita outcomes. The model is then used to analyze the impact of global trade liberalization on poverty in one of the sample economies, Indonesia. The article concludes with a discussion of 
the strengths and limitations of this approach for linking global trade liberalization and poverty in developing economies.

\section{Specialization of Earnings in a Sample of Developing Economies}

A key premise of this article is that in the short run household incomes will be differentially affected by global trade liberalization, depending on their reliance on sector-specific factors of production. For example, a household that earns all of its income from a family-run farm will be heavily dependent on the prices of agricultural products. If agricultural prices fall, household members may eventually find other employment, but this is likely to be difficult in the short run, particularly if members are not currently employed off-farm. This close link between farm household welfare and agricultural prices has also been observed in studies using annual household survey data (Chen and Wang 2001).

Because of the potential importance of specialized earnings sources in the analysis of short-run impacts of trade liberalization, their prevalence was examined using national household survey data for 14 countries in Africa, Latin America, and Southeast Asia. The surveys were selected on the basis of their availability through the World Bank, recent coverage (summers of 2001 and 2002), thorough treatment of household earnings, and match with the country coverage in the trade modeling database from GTAP version 5. This was the largest group that could be assembled at the time based on these criteria. The unit of analysis is the household, with equal sharing of income within the household assumed to obtain income on a per capita basis. ${ }^{4}$

The share of households with specialized earnings from agriculture (households that earn 95 percent or more of their income from agricultural profits) was plotted against GDP per capita, measured in purchasing power parity (PPP) terms (figure 1). Because workers in these households both work full-time in agriculture and are self-employed, they are unlikely to switch quickly to other activities if returns to farming fall. Likewise, because they are fully employed in agriculture, they are unable to quickly increase the amount of effort devoted to farming if returns rise, short of reducing their leisure time.

There is a negative correlation between GDP per capita and the share of households specialized in agriculture. In Malawi, the poorest country in the sample, nearly 40 percent of households have specialized earnings from agriculture. In Chile, the richest country in the sample, only about 6 percent of households have specialized earnings from agriculture. Although there are a few exceptions, for

4. The equal sharing assumption is clearly problematic, as it is only a special case of what would be found in a more general bargaining model of intrahousehold behavior (Bourguignon and Chiappori 1994). This assumption tends to understate income inequality, although the impact on poverty measures is less clear (Haddad and Kanbur 1990). 
FIgURE 1. Share of Households with Agriculture-Specialized Earnings and GDP per Capita

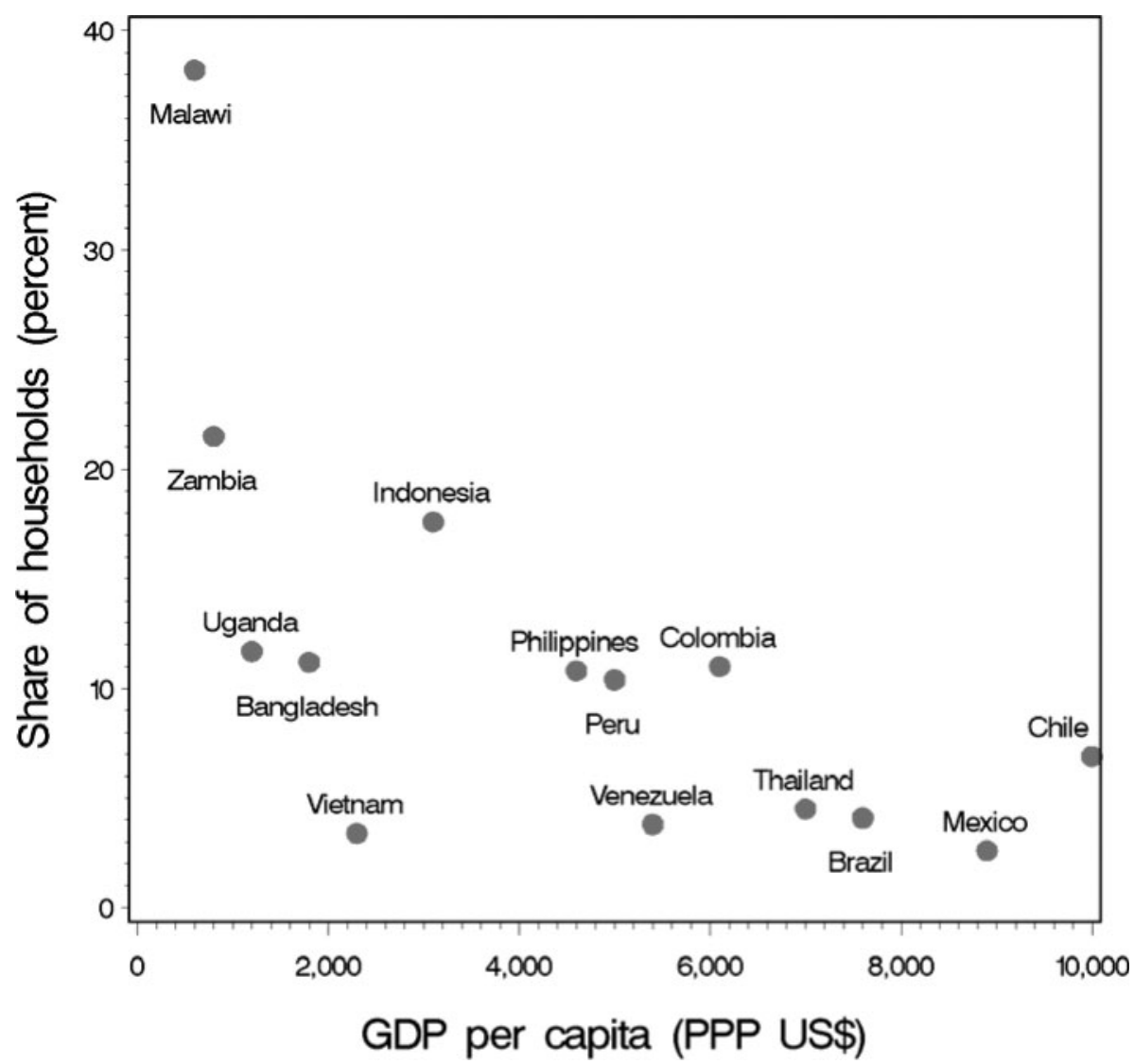

Source: Authors' calculations based on data from 1993-2002 household surveys and World Bank data on countries' GDP.

many developing economies the agriculture-specialized segment of the population is substantial, and the share is generally inversely related to per capita GDP.

But how distinct is this agriculture-specialized group? Does it warrant individualized treatment in the analysis? Consider the case of Indonesia, which falls in the middle of the sample. Although it is neither among the poorest countries nor among those with the highest share of agriculture-specialized households, it does have a significant proportion of agriculture-specialized households. A plotting of the distribution of households in the Indonesian survey with the data arranged by share of household income derived from agricultural profits ( $x$ axis) and log of income level ( $y$ axis) shows a bimodal distribution for agricultural specialization (figure 2). Although a majority of households receives little or no profit income from agriculture, a substantial minority (21 percent of the population) receives virtually all its income from self-employment 
Figure 2. Agriculture-Specialized Earnings in Indonesian Households and Income Level

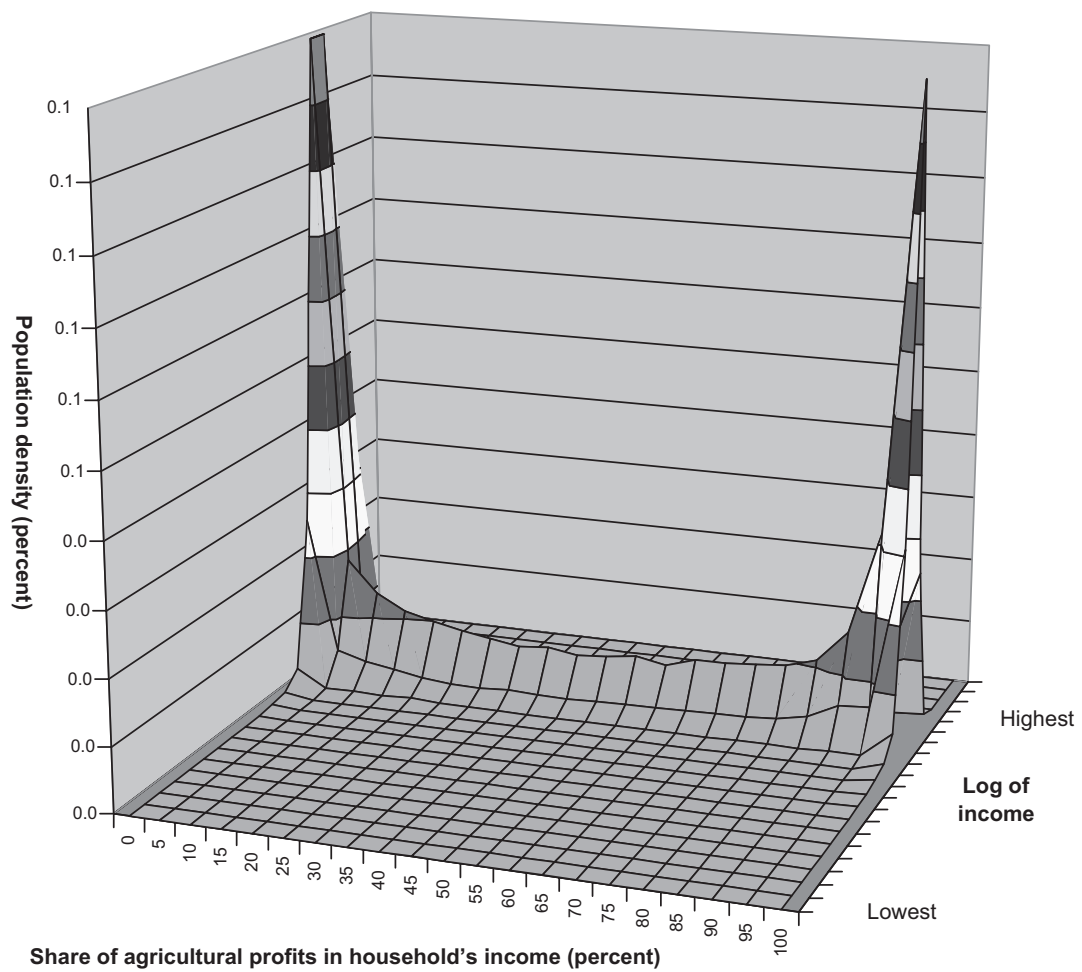

Source: Authors' calculations based on data from Indonesia 1993 household survey.

Table 1. Structure of Poverty Headcount in Indonesia by Earnings-Based Stratum (percent)

\begin{tabular}{lcccccr}
\hline Indicator & Agriculture & Nonagriculture & Wages & Transfers & Diversified & Total \\
\hline Share in total population & 21 & 15 & 18 & 1 & 44 & 100 \\
Share in total poverty & 34 & 11 & 7 & 3 & 45 & 100 \\
Poverty rate in stratum & 25 & 11 & 5 & 30 & 16 & 15 \\
\hline
\end{tabular}

Source: Authors' calculations based on Indonesia 1993 household survey data.

in farming (table 1), so isolating this group in a specific stratum looks like a good idea. $^{5}$

It looks like an even better idea based on the share of the impoverished population in this category. Although agriculture-specialized households

5. Note that although figures 1-5 use households as the unit of observation, table 1 uses population, assuming the equal sharing of income among household members. Thus this table reports that 21 percent of the population resides in the agriculture-specialized stratum. 
account for only about one-fifth of the population in Indonesia, they account for more than one-third ( 34 percent) of individuals with per capita incomes of less than $\$ 1$ a day (see table 1). Clearly, the fate of these households under trade liberalization could have an important effect on the national poverty rate.

The other type of household specialization that appears to be correlated with national per capita income in the sample is wage and salary specialization (figure 3). People in this group work for others. Because these wage-specialized households are wholly reliant on labor income, their earnings will be closely tied to changes in market wages. There is a strong positive correlation with per capita GDP at PPP prices. The poorest countries tend to have relatively few such households (less than 5 percent of total households in Uganda and Vietnam), whereas the richer countries tend to have more than 25 percent of their households in this category. This positive correlation is hardly surprising. Increased specialization is expected, along with more efficient formal labor markets, as countries become more developed.

FIGURE 3. Share of Households with Wage-Specialized Earnings and GDP per Capita

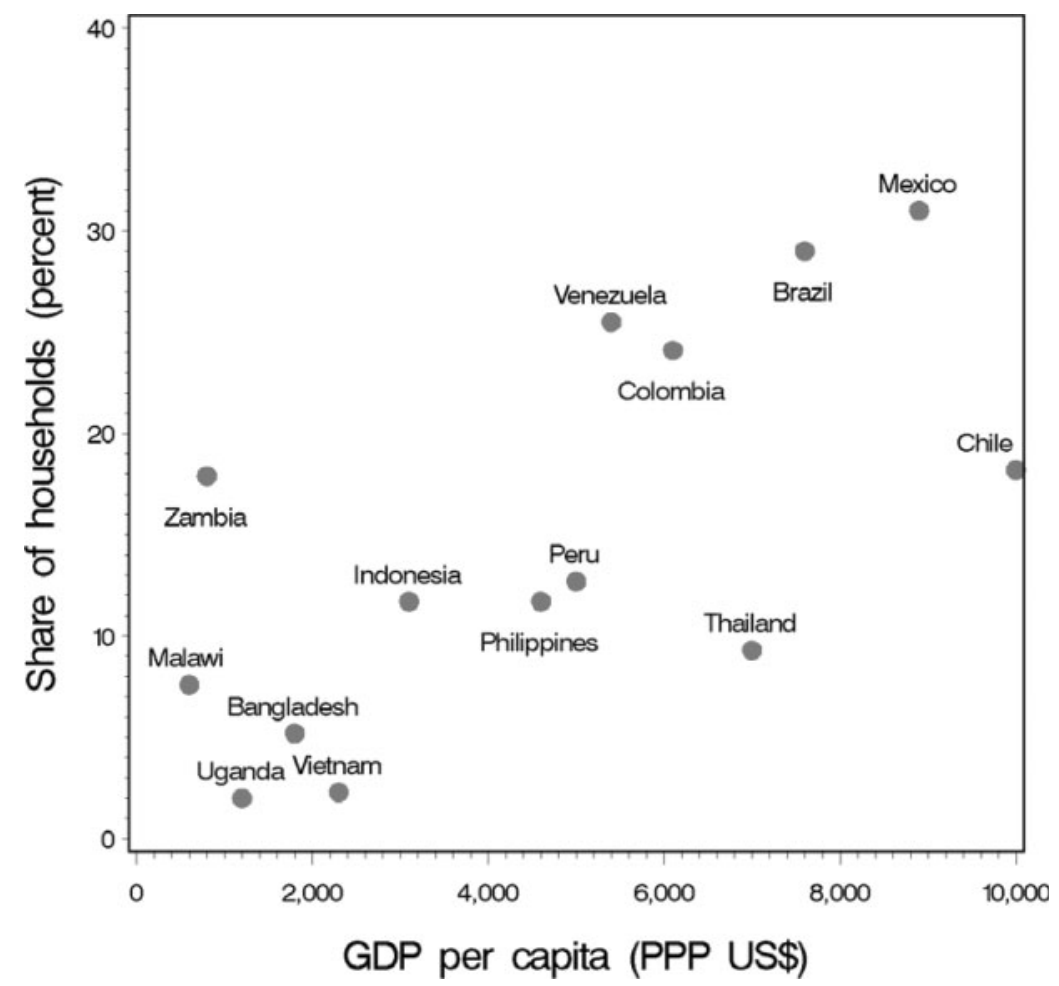

Source: Authors' calculations based on data from 1993-2002 household surveys and World Bank data on countries' GDP. 
FiguRE 4. Wage-Specialized Earnings in Indonesian Households and Income Level

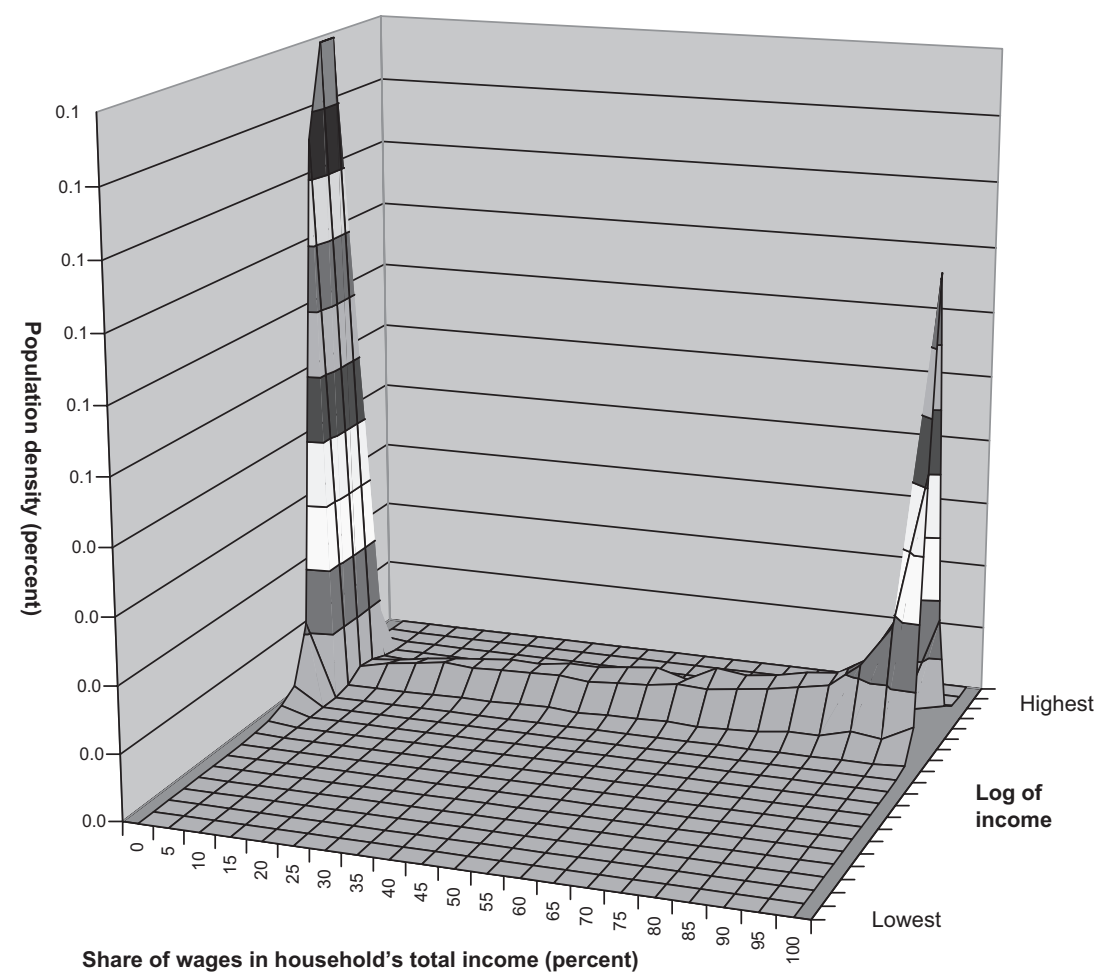

Source: Authors' calculations based on Indonesia 1993 household survey.

A plotting of a three-dimensional distribution of households in the Indonesia survey highlighting the share of household income obtained from wages and salaries again shows sharp peaks at the two extremes (figure 4). Although most households are not specialized in this dimension, there is a significant cluster above the 95 percent earnings share from wages and salaries. These households account for about 18 percent of the population and about 7 percent of the population under the poverty line (see table 1). Thus, in contrast to agriculturespecialized households, the wage-specialized households are disproportionately nonpoor. This is also evidenced in the modest stratum poverty headcount of 5 percent for wage-specialized households compared with 15 percent for the nation as a whole.

In addition to agriculture- and wage-specialized households, some households also specialize in nonagricultural profits (self-employed in nonagricultural sectors) and transfers and some households are not specialized (diversified households). Although the relative size of the transfer-specialized group appears to be positively correlated with per capita income, the household shares for the 
other two categories do not. For Indonesia, households wholly reliant on nonagricultural profits (for 95 percent or more of total income) account for 15 percent of the population and 11 percent of the poor, with a poverty rate somewhat below the national average (see table 1). Households specialized in transfers are a much smaller group (1.3 percent of the population) but disproportionately poor (2.6 percent of the national poor). Finally, the diversified group represents about 45 percent of both the total and the impoverished populations in Indonesia.

\section{Imputing Returns from Profit-type Income FOR LONG-Run AnAlysis}

Because returns (net of tax) to comparable factors of production are expected to be equalized across sectors in the long run, the boost to self-employed agricultural labor that occurs in the short run when world food prices rise will be shared with nonagricultural labor as more workers are drawn into farming (or fewer leave agriculture). Alternatively, when nonfarm wages rise, this improvement is expected to be shared eventually with self-employed farm laborers as they seek off-farm jobs. Thus, to identify the long-run impacts on individual households and groups, it is necessary to assess the underlying factor endowments of the selfemployed population. How much of observed agricultural and nonagricultural "profits" can be attributed to unskilled labor, and how much represents returns to land or capital? This type of earnings imputation is notoriously difficult, but it is essential to an analysis of the impacts of trade liberalization on poverty in the long run.

The first step in splitting reported agricultural and nonagricultural income into returns to capital, labor, and land is to impute income for each household member as the average wage of all workers in the economy with the same personal characteristics (age, education, skill, and industry) who earned wage income only. This imputed labor income for all household members involved in the family business is then subtracted from the reported profits of the household business. For greater accuracy, agricultural and nonagricultural business income are carefully separated, so that only imputed agricultural wages are subtracted from agricultural profits and only imputed nonagricultural wages are subtracted from nonagricultural profits. If no information on the nature of imputed wage is available, the industrial classification for the head of the household is used.

Next, the remaining profit-type agricultural income is split into returns to capital and returns to agricultural land. If the sum of imputed wages exceeds total reported business income, all operating surplus is classified as returns to labor and the capital return for this business is set to zero to avoid negative flows. Then property rental income directly reported by households is added to this composite to estimate total returns to capital and agricultural land. Because nonfarm land is treated as part of the nonfarm capital composite, this completes the task of imputation for nonagricultural profits. Ideally, information on 
Figure 5. Imputation of Labor Earnings for Self-Employed Agriculture Households in Indonesia

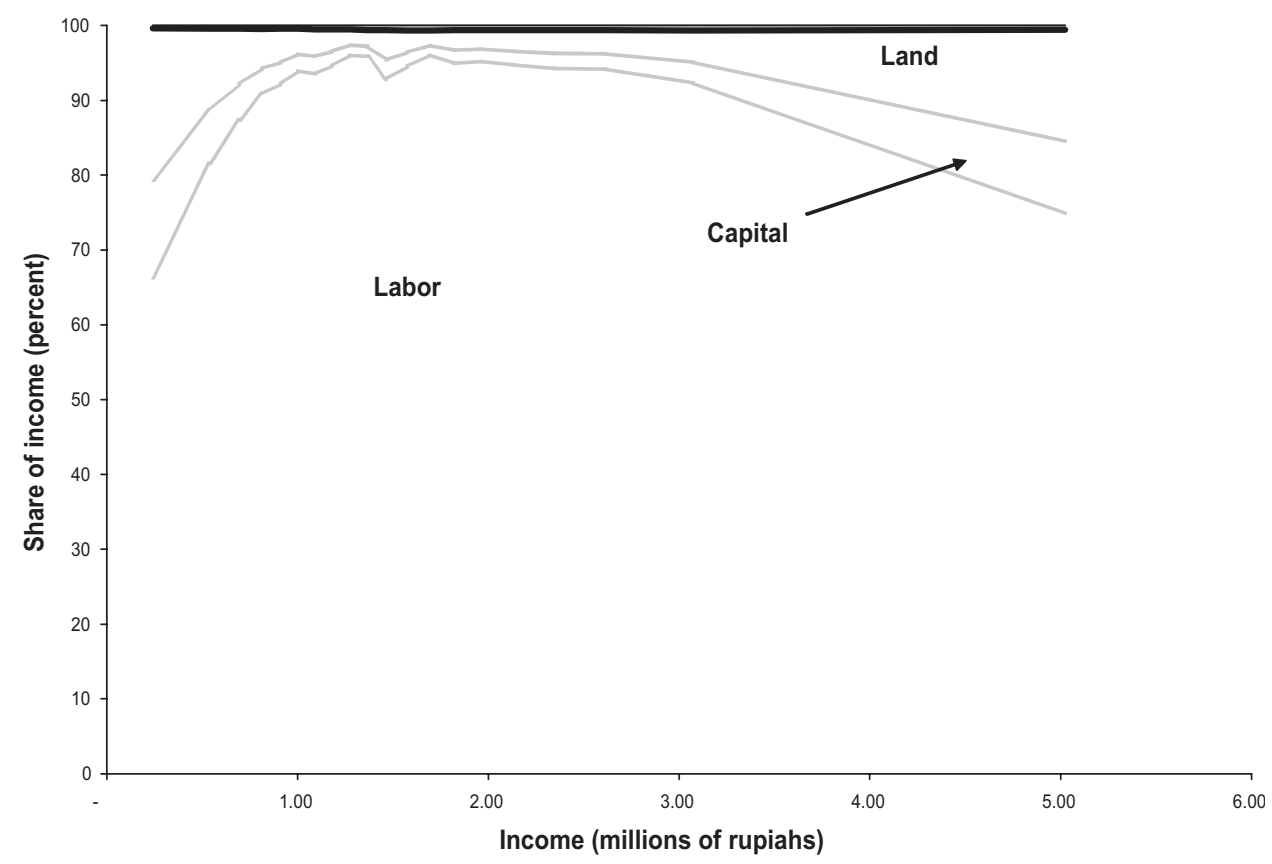

Source: Authors' calculations based on Indonesia 1993 household survey.

household farm land holdings would be used to split this remaining category of income for the agricultural enterprises, but attempts to do so failed. Therefore, a simple share-based split of nonwage, profit-type income in agriculture is used. To make it consistent with the trade liberalization simulation analysis, the national average share of farmland in total nonlabor agricultural earnings was taken from the GTAP 5 database.

For Indonesia, the results of this imputation procedure show that for most households employed in agriculture more than 80 percent of their income represents returns to family labor (figure 5). ${ }^{6}$ The residual share of income attributed to capital and land is greatest at the lowest and highest income levels. The very poorest households have a very low endowment of human capital, because they have not only low incomes but also a low share of imputed labor within that low income level. ${ }^{7}$ The same U-shaped relationship between capital's

6. This imputation was also undertaken for the other countries in the sample, and the results are discussed in Ivanic (2003).

7. Since children under 12 years of age are typically excluded from the employment questions on household surveys, it is also possible that these apparent returns to non-labor inputs are really returns to child labor. This pattern emerges in many of the other countries as well. 
Figure 6. Imputation of Labor Earnings for Self-Employed Nonagriculture Households in Indonesia

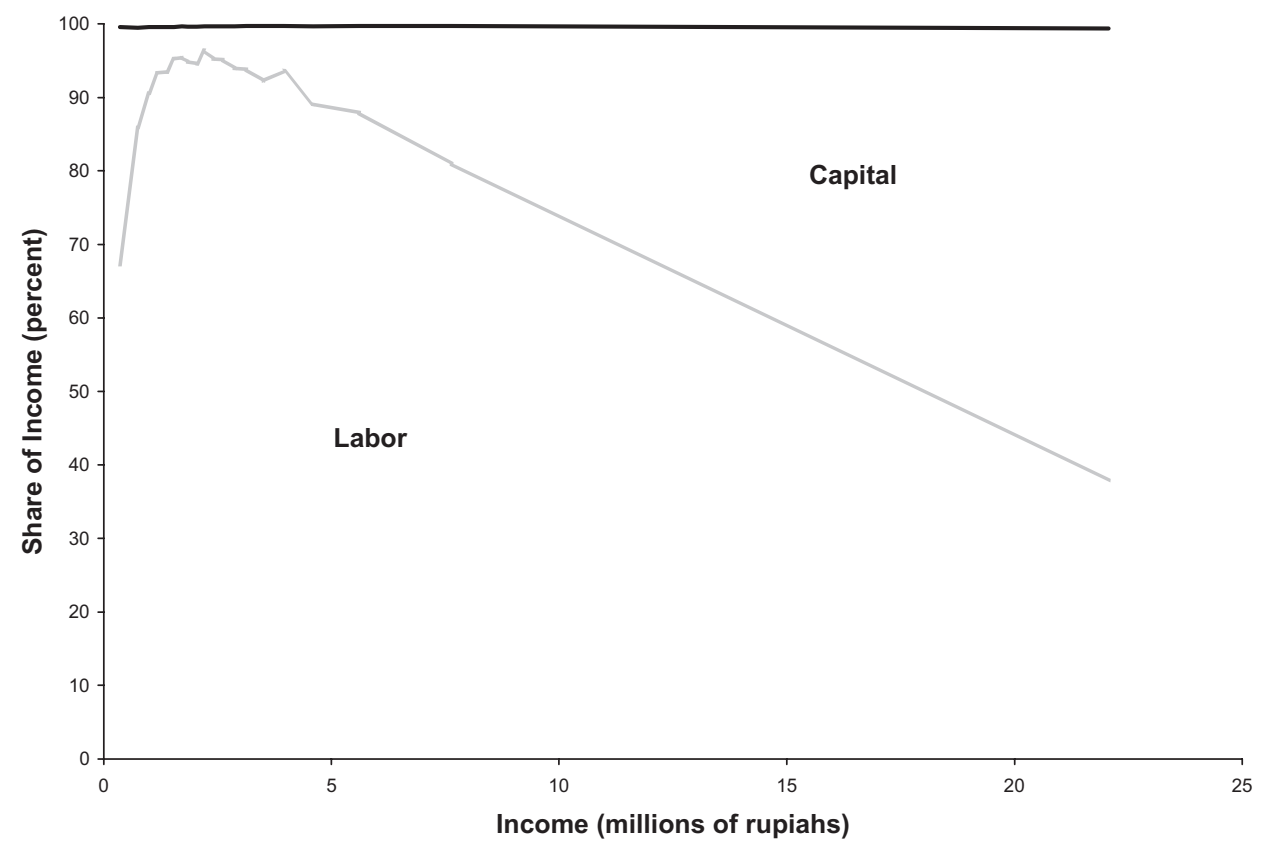

Source: Authors' calculations based on Indonesia 1993 household survey.

share of imputed income and per capita household income is found for the nonagriculture households, but the shares for capital income are much larger, especially at the higher income levels (figure 6).

One common problem in household surveys is underreporting of income. In a study of income distribution in Organisation for Economic Co-operation and Development (OECD) countries Atkinson and others (1995) find evidence of systematic income underreporting of 10-20 percent. Underreporting is likely to be even greater in developing economies, as is evident when the share of estimated gross factor income in agriculture and nonagriculture are computed for Indonesia. ${ }^{8}$ The survey shows the share of gross factor income earned in agriculture to be nearly half, whereas it is only about 20 percent in the national accounts. ${ }^{9}$ To reconcile these two databases in this key dimension by adjusting for underreporting of capital income, nonagricultural profit-type income reported by the wealthiest households in the survey is adjusted to reflect the same agriculture-nonagriculture mix of earnings as in the GTAP 5 database. This

8. To match up with the survey data definitions, agriculture is defined as including fisheries and forestry.

9. This figure comes from the 1997 GTAP 5 database for Indonesia. It is based on an updated version of the 1993 Indonesia input-output table (Biro Pusat Statistik). 
Taвle 2. Estimated Shares of Gross Factor Earnings in Indonesia (percent)

\begin{tabular}{lccr}
\hline Factor & Agriculture & Nonagriculture & Total \\
\hline Unskilled wage & 5.1 & 12.7 & 17.8 \\
Skilled wage & 0.0 & 7.8 & 7.8 \\
Profits & 14.5 & 59.9 & 74.5 \\
Land & 1.5 & 0.0 & 1.5 \\
Capital & 5.3 & 37.9 & 43.2 \\
Natural resources & 0.9 & 2.0 & 2.8 \\
Imputed unskilled labor & 6.9 & 9.6 & 16.5 \\
Imputed skilled labor & 0.0 & 10.4 & 10.5 \\
Total & 19.6 & 80.4 & 100.0 \\
\hline
\end{tabular}

Source: Authors' calculations based on Indonesia 1993 household survey and GTAP 5 data.

approach is supported by the work of Mistiaen and Ravallion (2003), who find that underreporting of income is greatest for the rich. ${ }^{10}$

The factor composition of GTAP's gross national earnings is next adjusted in line with that suggested by the survey data (Ivanic 2003). This has the important consequence of increasing the share of skilled labor in the economy. Also, as a result of the substantial imputed returns to self-employed labor, the capital intensity of the GTAP database is reduced for Indonesia. ${ }^{11}$ The resulting matrix of gross factor earnings shares for Indonesia shows that imputed labor income accounts for more than a third of profits (table 2). Total labor earnings are about equally divided between wages and salaries and imputed labor income. Skilled labor accounts for about half the imputed income in the nonagricultural sector, but almost none in agriculture, which relies almost entirely on unskilled labor.

\section{Analytical Framework}

Analysis of the impacts of trade liberalization on the poor begins with the specification of a utility function and an associated consumer demand system for determining household consumption and the maximum utility attainable by the household at a given set of prices and income. A modified version of the GTAP global trade model is then used to generate the price changes for the microsimulation analysis.

10. An alternative would be to increase all nonfarm profit-type income by the same proportion. However, when that is done, the income adjustment is sufficient to lift most of the affected households out of poverty. This does not seem realistic, and given the focus on poverty, the adjustment was made for the richest households instead.

11. The apparently excessively capital intensity of the GTAP database for developing economies, particularly in Southeast Asia, points to a pervasive problem of underestimating returns to self-employed labor. Using the survey data in this way promises to improve the GTAP database for these countries. 


\section{Specifying the Microsimulation Model}

The utility of the household at the poverty line (here referred to as the marginal household) is defined as the poverty level of utility. If a household's utility falls below this level following trade liberalization, it is considered to have fallen into poverty. If a household rises above this level of utility, it is considered no longer in poverty. The poverty level of utility can also be used to compute the poverty gap-the amount of transfer required to lift extremely poor households up to the poverty line, permitting them to achieve the poverty level of utility.

This approach to determining the poverty line appears preferable to that proposed by Decaluwé and others (1999), who identify a basic needs bundle of goods and implement it in a linear expenditure system (LES) model of consumption in which households below the poverty line cannot substitute among consumption items when prices change. In contrast, the approach used here permits such substitution and does not rely on the somewhat artificial definition of a fixed basket of basic needs.

This study uses Rimmer and Powell's (1992a, 1992b, 1996) implicit directly additive demand system (AIDADS) to represent consumer preferences because it captures expenditure patterns across the global income spectrum (see also Cranfield and others 2000, 2002). AIDADS has been widely estimated on international cross-section data, and it performs well out of sample compared with other demand systems (Cranfield and others 2003). This functional form may be viewed as a generalization of the popular, but restrictive LES. But unlike the LES, AIDADS allows for nonlinear Engel responses while maintaining a parsimonious parameterization of consumer preferences.

The budget share form of AIDADS is given as

$$
\lambda_{n}=\left(p_{n} \gamma_{n} / y\right)+\left(\left[\alpha_{n}+\beta_{n} \exp (u)\right] /[1+\exp (u)]\right)\left(1-p^{\prime} \gamma / y\right) \forall n,
$$

where $\lambda_{n}$ is the budget share of good $n ; p_{n}$ is the price of good $n ; y$ is income; $\gamma_{n}$, $\alpha_{n}$, and $\beta_{n}$ are unknown parameters; $u$ represents utility; and the final term represents the share of discretionary spending in total income. The following parametric restrictions are used to ensure well-behaved demands: $0 \leq \alpha_{n}, \beta_{n} \leq 1$ for all $n$, and $\sum_{n=1}^{N} \alpha_{n}=\sum_{n=1}^{N} \beta_{n}=1$. If $\alpha_{n}=\beta_{n}$ for all goods, then AIDADS simplifies to the LES. By replacing the values of the marginal budget shares in the LES with more general terms that are functions of a value that varies with utility, AIDADS allows for marginal budget shares that vary across per capita expenditure levels in a fairly general manner. Moreover, the average budget shares from AIDADS also vary nonlinearly across expenditure while remaining within the unit interval.

This study also draws on recent work by Cranfield (1999) and Cranfield and others (2004), who estimate the parameters of a complete demand system while simultaneously using data on the distribution of expenditure by quintile to permit recovery of the unobservable distribution of expenditures for each quintile. This approach requires data typically used in demand system estimation (prices 
Table 3. Estimated aidads Parameter Values, Noncountry Specific

\begin{tabular}{lcccccc}
\hline Parameter & Grains & Livestock & Other food & Nondurables & Durables & Services \\
\hline$\gamma$ & 0.002 & 0.000 & 0.000 & 0.000 & 0.000 & 0.000 \\
$\alpha$ & 0.233 & 0.203 & 0.333 & 0.151 & 0.035 & 0.044 \\
$\beta$ & 0.000 & 0.051 & 0.047 & 0.262 & 0.113 & 0.528 \\
\hline
\end{tabular}

Source: Authors' estimates based on data from the International Comparison Project and the available data on expenditure inequality.

and per capita quantities and expenditures), in addition to survey-based information on the distribution of expenditure (or income). Rather than estimating a model that predicts a budget share for each good on a per capita basis in each observation, the framework approximates the distribution of expenditure, estimates demand system parameters consistent with the demand and expenditure data (including the distribution information), and predicts budget shares for each good across expenditure levels within each national observation.

Consumption, price, and expenditure data from 113 countries in the 1996 International Comparisons Project (ICP) data set are used for the demand system portion of the model (Kravis and others 1982). Survey data from the 14 countries for which this formation is available are supplemented with quintile data from the Deininger and Squire (1996) database and various issues of the World Bank's World Development Report $(1992,1993,2000) .{ }^{12}$ It is important to note that the recovered expenditure distribution aggregates back to the per capita expenditure levels in the ICP data, as well as reproducing the observed distribution of total expenditure. The ICP consumption and price data are aggregated up to six goods: staple grains, livestock products, other food products, other nondurable goods, durable goods, and services. The emphasis on food products is appropriate for this poverty-focused study, because poor households spend a large share of their income on food.

The non-country-specific estimated AIDADS parameters (table 3) may be used to predict spending patterns across the income spectrum, even in countries where household expenditure surveys are not available. This makes the AIDADS estimation of parameters particularly well suited to a multicountry analysis of trade and poverty. A few observations about these parameters are in order. First, the estimated subsistence budget shares $\left(\hat{\gamma}_{n}\right)$ for all products except for staple grains are zero. Second, the parameters $\hat{\alpha}_{n}$ and $\hat{\beta}_{n}$ represent estimates of the bounds of the AIDADS marginal budget shares. So $\hat{\alpha}_{n}=0.233$ indicates that at low income levels grains account for as much as 23.3 cents of each additional

12. In the cases in which there are no original survey data and only quintile data are available, a finer distribution of expenditure is approximated across 15 expenditure levels for each observation in the ICP data set. These 15 expenditure levels are equally allocated across the five quintiles, so that there are three expenditure levels within each quintile. 
Table 4. Calibrated AIDAds Parameter Values for Indonesia

\begin{tabular}{lcccccc}
\hline Parameter & Grains & Livestock & Other food & Nondurables & Durables & Services \\
\hline$\gamma$ & 0.002 & 0.000 & 0.000 & 0.000 & 0.000 & 0.000 \\
$\alpha$ & 0.314 & 0.151 & 0.308 & 0.135 & 0.045 & 0.046 \\
$\beta$ & 0.000 & 0.038 & 0.043 & 0.231 & 0.142 & 0.547 \\
\hline
\end{tabular}

Source: Authors' estimates based on data from the International Comparison Project and the available data on expenditure inequality.

dollar of expenditure, whereas $\hat{\beta}_{n}=0$ suggests that at high income levels changes in expenditure on grains are negligible with an increase in expenditure. Livestock and other food also show values of $\hat{\alpha}_{n}>\hat{\beta}_{n}$, thereby dictating that marginal expenditures fall with income, whereas nondurables, durables, and services show values suggesting that marginal expenditures rise with income.

As is generally done in microsimulation studies, this international estimation of the AIDADS parameters is followed by a calibration step in which the values of $\alpha_{n}$ and $\beta_{n}$ are altered to ensure that predicted demands equal observed demands for the country in question. ${ }^{13}$ While some of the parameters change considerably (most notably grains and livestock products, see table 4), they retain the qualitative relationships that were observed in the cross-section estimates (see table 3).

The predicted expenditure patterns for households in Indonesia across the full spectrum of expenditure show a monotonically declining pattern for the grains budget share, as expected from the parameters in table 4, and for livestock and other food, albeit at a slower rate (figure 7). The budget shares for nonfood goods, including nondurables, durables, and services, follow an increasing pattern.

A natural alternative to using the AIDADS function would be to predict expenditure patterns from the survey data, either by econometrically estimating a demand system (although it would be difficult without obtaining separate price data) or by using budget shares to create a local measure of welfare changes, as in Chen and Ravallion (2003). This would not be possible in 6 of the 14 sample countries, because expenditure data are not available in the surveys for those countries. However, such data are available for Indonesia, and preliminary comparisons indicate that the predicted pattern of expenditure is consistent

13. After a common AIDADS demand system is estimated across all countries in the ICP sample, the parameters are adjusted on a country-by-country basis to match observed per capita spending patterns. First, the subsistence budget share is taken as fixed, and the ratio of the actual discretionary budget share to the fitted discretionary budget share is used to rescale the remaining parameters of the AIDADS demand system. Second, the level of utility and a scaling parameter in the AIDADS utility function are calibrated to match the observed expenditure pattern in each country. The result is a country-specific AIDADS utility function and demand system that matches actual consumption. 
Figure 7. Predicted Budget Shares for Indonesia Using Calibrated Parameters, 1997

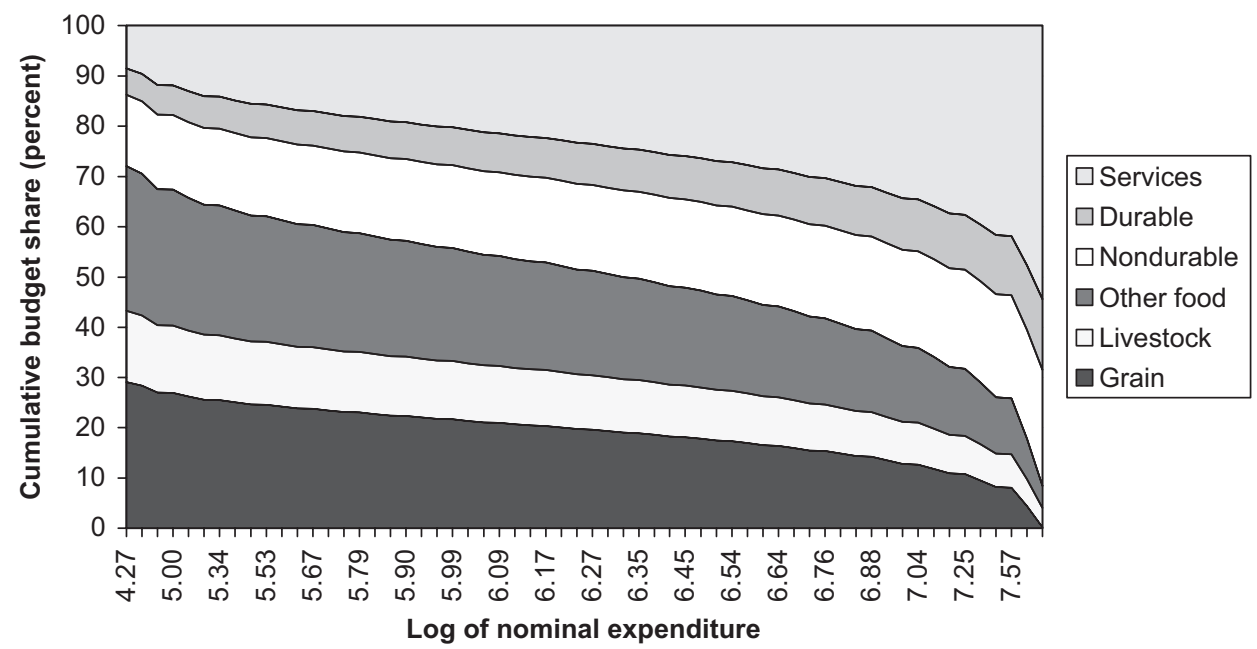

Source: Authors' estimates based on ICP 1996 data updated to 1997.

with the pattern from the survey. ${ }^{14}$ Given the convenience of working with an explicit demand system, as well as the consistency obtained by using the same demand system in the global trade model, this appears to be a sound choice.

Next, the per capita utility function, which is common across all individuals within each country, can be used to specify the household microsimulation model, which involves maximizing per capita utility, subject to a per capita budget constraint, based on the households' overall endowments.

Choose $\left(x_{1 k}, \ldots, x_{i k}, \ldots, x_{n k}\right)$, where $i$ indexes the commodities and $k$ households. To maximize $u_{k}$

$$
\begin{gathered}
\text { subject to } \sum_{i=1}^{n} U_{i}\left(x_{i k}, u_{k}\right)=1, \\
U_{i}\left(x_{i k}, u_{k}\right)=\varphi_{i k}\left(u_{k}\right) \ln \left(\left[x_{i k}-\gamma_{i}\right] / A \exp \left[u_{k}\right]\right) \forall i \\
\varphi_{i k}\left(u_{k}\right)=\left[\alpha_{i}+\beta_{i} \exp \left(u_{k}\right)\right] /\left[1+\exp \left(u_{k}\right)\right], \text { and } \\
\sum_{i=1}^{n} p_{i} x_{i k}=Y^{k}=\Sigma_{f} W_{f} \bar{E}_{f}^{k}-\Sigma_{f} \delta_{f} P_{f} \bar{E}_{f}^{k}+T^{k} Y .
\end{gathered}
$$

In this formulation, equations 2 and 3 define the implicitly additive AIDADS utility function with parameters $\alpha_{i}, \beta_{i}, \gamma_{i}$, and $A$ and the marginal budget share as

14. Because the base years and commodity definitions differ between the ICP data and the survey data, the per capita expenditure shares also differ. 
defined by equation 4 . Equation 5 is the per capita budget constraint, with income defined net of depreciation and inclusive of any transfers, ${ }^{15}$ where $W_{f}$ is the wage paid to endowment $\bar{E}_{f}^{k}, \delta_{i}$ is the geometric rate of depreciation for endowment $\bar{E}_{f}^{k}$ (zero for noncapital items), $P_{f}$ is the cost of replacing depreciable endowment $f$ (the capital goods price), and $T^{k}$ is the transfer rate for household $k$, which is assumed to be a constant share of net national income, $Y$.

The subsequent analysis uses survey-based observations on endowments and transfers. The depreciation rate for capital stock is obtained from the national accounts. Trade liberalization will alter the wages associated with each endowment, the price of capital goods, and transfers. The resulting level of income for household $k$ can be computed using equation 5. Once the new income level is known, it can be combined with the new vector of commodity prices to compute expenditure on each good, and hence individual demands, using equation 1. Equations 2-4 are then used to compute per capita utility, and the postliberalization utility level is used in computing the change in poverty headcount. Equations 1-5 can also be used to compute the transfer necessary to bring a given impoverished household up to the poverty line.

\section{Modeling Trade Liberalization}

In theory, the microsimulation model could be used in conjunction with any policy simulation framework capable of yielding the requisite price changes. In practice, however, there are substantial challenges in marrying the two analytical frameworks. Most important, the two models must be consistent in their characterization of earnings and spending-no small task as the preceding discussion of the earnings data in table 2 shows. ${ }^{16}$

This analysis uses a modified version of the GTAP global trade model (Hertel 1997) to generate the price changes to be fed into the microsimulation analysis. The modifications are aimed at obtaining consistency in national per capita consumption between the global trade model and the microsimulation framework.

Building on the GTAP model has several advantages. First, it is a global model, so it is capable of producing results from global trade liberalization scenariosan important objective of the analysis undertaken here. Second, it is a relatively standard CGE model, assuming perfect competition and differentiated products in international trade. Owing in part to this simplicity, GTAP is the most widely used global trade model, with more than 1,000 users around the

15. The only taxes that are explicitly modeled are indirect taxes, which are reflected in the difference between consumer prices and gross factor earnings.

16. Note that the postsimulation incidence analysis abstracts from the potential impact that the resulting changes in income distribution might have on relative prices. Given the relatively modest shifts in income, coupled with modest differences in consumption shares, the resulting approximation error is unlikely to be very severe. This issue could be resolved if the disaggregated households were directly incorporated into the trade policy model (Cogneau and Robilliard 2000). This would be a major undertaking in a relatively detailed CGE model of the global economy. 
world. Demonstrating how to make it consistent with the microsimulation model opens the door to other analysts interested in addressing distributional issues. A final reason for using this framework is the regional disaggregation in the GTAP 5 database, which is large and continually expanding (13 regions in version 1, 66 regions in version 5, and a projected 87 regions in version 6).

Once gross factor earnings in the microsimulation and GTAP models have been reconciled (see previous discussion), several further adjustments are required to fully reconcile these analytical frameworks. First, in the specification of consumer demand in the GTAP model the constant difference of elasticities demand system is replaced by the econometrically estimated AIDADS demand system discussed previously, ${ }^{17}$ making specification of consumer demand in the two frameworks fully consistent. Because the ICP-based consumer expenditure shares are evaluated at consumer prices, whereas the GTAP consumption vector is evaluated at producer prices, wholesale, retail, and transport margins applied to goods destined for private consumption must be explicitly modeled. These are modeled using a Cobb-Douglas production function, which combines the producer good and margin services to produce the consumer good. This is important, because these margins can perform an important insulating role when trade liberalization alters world prices and hence domestic producer prices (Winters and others 2003).

Depreciation, a critical component of the macroeconomic accounts, is absent from the survey data. To reconcile the net income effects of trade liberalization between the two frameworks, national depreciation is shared out among the households in the microsimulation model in proportion to estimated gross earnings from capital. ${ }^{18} \mathrm{~A}$ final problem relates to transfer payments, which are unobserved in the GTAP 5 database but are assumed to be proportional to net national income. Accordingly, government spending, tax revenues, and foreign borrowing, which are explicitly modeled in GTAP, are also tied to net national income in the model closure adopted in the subsequent simulation analysis. ${ }^{19}$ Following Harrison and others (2002a, 2002b) forgone tariff revenue is replaced by a value-added tax to maintain tax's share in net national income. ${ }^{20}$

17. Because the AIDADS parameters are modified to replicate observed per capita consumption in each region, the parameters differ by country (see previous discussion).

18. National depreciation is obtained from the GTAP 5 data base. This estimate comes originally from the World Bank. The share of depreciation in gross capital income is computed and applied to the microsimulation data base.

19. This fixed-share assumption for government spending is not strictly true in the standard closure for version 6.1 of the GTAP model because of the nonhomotheticity of private consumption. To make this hold exactly, a preference shift for regional household utility function is introduced such that the shares of private and public consumption and savings in net national income are fixed.

20. GTAP users will recognize that the textile and apparel quota rents are treated as export taxes in the model. However, these rents rarely accrue in full to the government, so they have been omitted from the tax replacement equations. 
IV. Protection Estimates and the Price Effects of Multilateral Trade Liberalization

The GTAP 5 database, documented in Dimaranan and McDougall (2002), incorporates relatively recent information on merchandise trade and agricultural protection. Agricultural tariffs are derived from the Agricultural Market Access Database and are for 1998 (Gibson and others 2002). Nonagricultural tariff data are for 1997, or the most recent year, and come from the World Integrated Trading System maintained by the United Nations Conference on Trade and Development and the World Bank. The only nontariff trade barriers in the database relate to export measures. Agricultural export subsidies for 1998, as reported to the WTO, are incorporated, as are the quota rents associated with restrictions on textile and apparel exports to North America and Europe. ${ }^{21}$

The trade liberalization experiment removes the tariffs and quotas. It does not attempt to capture the impact of prospective liberalization of direct trade in services or barriers to international investment or the movement of people in the services sectors. The liberalization experiment also leaves domestic agricultural subsidies in place. Modeling these subsidies requires considerable care given the decoupled nature of many of these programs. These will be tackled in future work.

Indonesia's 1998 tariffs in primary agriculture are lower than those of other developing economies and far lower than those for developed economies (table 5). Indonesia's tariffs are higher for processed food imports, particularly beverages and tobacco products, putting it on a par with other developing economies for this combined category of imports. Indonesia's average tariffs on textiles and apparel products are relatively high, as are its tariffs on motor vehicles.

This study explores the impact of trade liberalization using both short-run and long-run closures. The short run assumes that wage and salaried laborers are mobile across sectors, but that capital, land, and self-employed labor are immobile. The returns to this group of factors are combined into sectoral "profits" corresponding to the agriculture and nonagriculture profits reported in the household surveys. The long-run closure assumes that self-employed labor is perfectly mobile and perfectly substitutable with wage labor of the same skill category. It also assumes that capital is perfectly mobile across sectors, whereas farm land is partially mobile across uses within the agricultural sector. ${ }^{22}$

Aggregated price changes for global trade liberalization are reported relative to the model's numeraire, the average price of primary factors worldwide (table 6). ${ }^{23}$ Consider first the total effects. A rise in primary factor prices in Indonesia (both

21. For ease of comparison in table 5, these have been placed on a cost, insurance, and freight basis and combined with the average import tariffs on textiles.

22. In this long-run closure, the elasticity of transformation of agricultural land across uses is set at -1.0 , the default value in the GTAP parameter file.

23. Note that the model generates these price changes for all regions in the model. Although this study explores the implications for Indonesia only, the analysis could easily be extended to the other 13 countries for which survey data have been incorporated into the model. 
Table 5. Average Tariff Rates for Indonesia, Developing Economies, and Developed Economies

\begin{tabular}{lccc}
\hline Product & Indonesia & Developing Economies & Developed Economies \\
\hline Primary agricultural goods & 7 & 27 & 13 \\
Rice & 6 & 14 & 91 \\
Wheat & 2 & 24 & 64 \\
Feedgrains & 4 & 60 & 14 \\
Other agriculture & 8 & 23 & 11 \\
Oilseeds & 7 & 37 & 25 \\
Raw sugar & n.a. & n.a. & n.a. \\
Meat and livestock & n.a. & n.a. & n.a. \\
Raw milk & 2 & 25 & 3 \\
Forestry & 1 & 3 & 1 \\
Fishing & 8 & 9 & 3 \\
Fats and oils & 10 & 28 & 9 \\
Processed food & 15 & 30 & 20 \\
Meat & 17 & 35 & 23 \\
Dairy & 7 & 30 & 25 \\
Rice & 0 & 19 & 72 \\
Sugar & 1 & 8 & 38 \\
Other processed food & 16 & 25 & 18 \\
Beverages and tobacco & 86 & 47 & 11 \\
Textiles, apparel & 16 & 16 & 11 \\
Textiles & 16 & 16 & 7 \\
Apparel & 25 & 15 & 14 \\
Other manufactures and mining & 10 & 9 & 2 \\
Automobiles & 42 & 5 & 2 \\
Electronics & 9 & 9 & 2 \\
Other manufactures & 5 & 9 & 2 \\
Wood and paper & 6 & 9 & 1 \\
Mining & 3 & 9 & 0 \\
Petrochemicals & 8 & 9 & 2 \\
Metals & 9 & 9 & \\
\hline & & 9 & 2 \\
\hline
\end{tabular}

Note: n.a. is not applicable (nontraded goods).

Source: Authors' calculations based on GTAP 5 data.

short- and long-run) means that Indonesia experiences a real appreciation as a result of this trade liberalization experiment. That is, increased demand for Indonesia's exports bids up its prices relative to the world average. On the commodity side, Indonesian food prices rise as developed countries reduce agricultural protection and the European Union and the United States curb their exports of subsidized products. This price hike is not offset by the reduction of Indonesia's relatively modest agricultural tariffs. In contrast, the producer prices of durables and nondurables fall substantially in the short run, resulting in a change in relative prices between food and nonfood merchandise. Not surprisingly, the price of services moves closely with wage rates, which rise strongly in Indonesia relative to the rest of the world as a whole. The rise in the price of services means that the (consumer) price changes for margin-inclusive nonfood goods are moderated. 


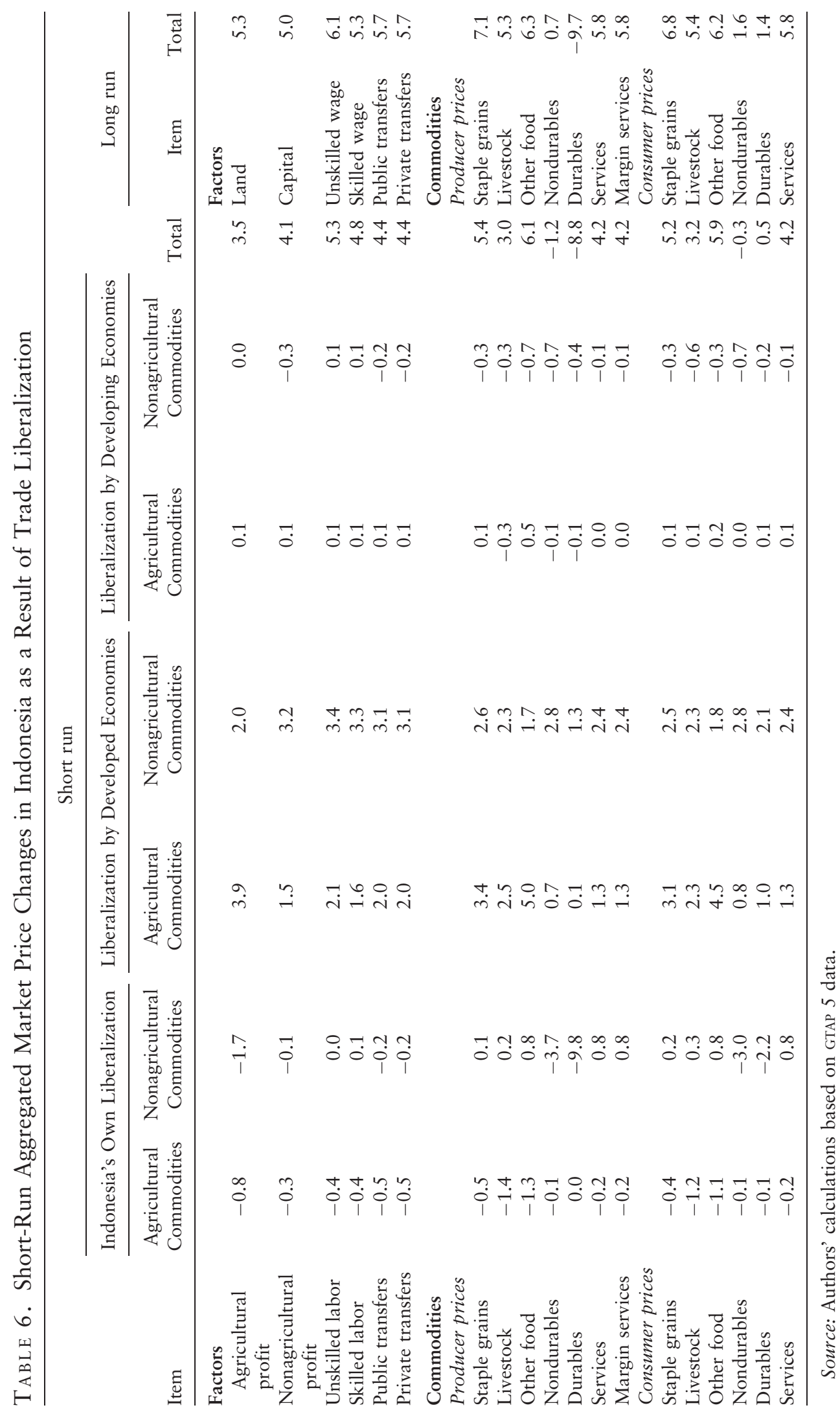


Because the AIDADS demand system employed in the postsimulation analysis is estimated at consumer prices, the vector of consumer price changes (bottom panel of table 6) is pertinent to this evaluation of household welfare.

The total short-run price impacts of global trade liberalization are decomposed into the components attributable to Indonesia's own liberalization, as well as those attributable to liberalization in other developing and developed economies using the method of Harrison and others (1999). For each country group the effects of farm and food liberalization (agriculture) are distinguished from the effects of other merchandise trade liberalization (nonagriculture). The most striking finding of this decomposition is the dominance of developed country trade liberalization in Indonesian earnings impacts (see table 6). Agricultural profits are largely driven by developed country agricultural liberalization, whereas nonagricultural profits are dominated by the elimination of developing economy nonagricultural trade barriers. The effects on earnings are much stronger than those of Indonesia's own liberalization. Furthermore, although trade liberalization in other developing countries has an ambiguous effect on factor returns in Indonesia, all of these Indonesian earnings respond positively to liberalization in developed areas.

The decomposition of aggregated commodity price effects of trade liberalization shows that developed country trade liberalization accounts for the bulk of the food price increase (see table 6). For durables and nondurables, developed country liberalization results in modest producer price increases, but these are more than offset by the price-depressing effect of Indonesia's own liberalization. For services, both Indonesia's own liberalization and developed country liberalization contribute to the price rise.

In the long run, with self-employed labor and capital mobile across sectors, their returns increase somewhat more than in the short run, and the increase in agricultural profits is concentrated in land rents (see table 6). Food prices rise more evenly in the long run, with the movement of land, labor and capital encouraging increased product supplies, particularly for staple grains (rice). Nondurable producer prices now rise slightly rather than falling. The producer price of durables falls somewhat more in the long run and the rise in the price of services is somewhat larger when factors are fully mobile.

\section{Poverty Impacts}

This section turns to the microsimulation results to examine the impact of trade liberalization on different types of households in Indonesia. It begins with an analysis of the poverty impacts and then explores the impacts across the entire income distribution.

\section{Summary Measures of Poverty}

Short-Run Effects. In the short run the number of poor is projected to fall for the nonagriculture-, wage-, transfer-specialized, and diversified strata, with the 
TABLE 7. Short- and Long-Run Impacts of Global Trade Liberalization on the Poverty Headcount in Indonesia (percentage change)

\begin{tabular}{|c|c|c|c|c|c|c|}
\hline & $\begin{array}{l}\text { Agriculture } \\
\text { Specialized }\end{array}$ & $\begin{array}{l}\text { Nonagriculture } \\
\text { Specialized }\end{array}$ & $\begin{array}{c}\text { Labor } \\
\text { Specialized }\end{array}$ & $\begin{array}{c}\text { Transfer } \\
\text { Specialized }\end{array}$ & Diversified & Total \\
\hline \multicolumn{7}{|l|}{$\begin{array}{l}\text { Indonesia's own } \\
\text { liberalization }\end{array}$} \\
\hline $\begin{array}{l}\text { Agricultural } \\
\text { commodities }\end{array}$ & 0.4 & -0.6 & -0.4 & -0.3 & -0.1 & 0.0 \\
\hline $\begin{array}{l}\text { Nonagricultural } \\
\text { commodities }\end{array}$ & 3.1 & -0.2 & -0.4 & 0.1 & 1.3 & 1.6 \\
\hline \multicolumn{7}{|l|}{$\begin{array}{l}\text { Developed country } \\
\text { liberalization }\end{array}$} \\
\hline $\begin{array}{l}\text { Agricultural } \\
\text { commodities }\end{array}$ & -2.4 & 2.6 & 1.5 & 1.2 & -0.1 & -0.5 \\
\hline $\begin{array}{l}\text { Nonagricultural } \\
\text { commodities }\end{array}$ & 0.4 & -2.0 & -2.4 & -1.4 & -1.0 & -0.7 \\
\hline \multicolumn{7}{|l|}{$\begin{array}{l}\text { Developing country } \\
\text { liberalization }\end{array}$} \\
\hline $\begin{array}{l}\text { Agricultural } \\
\text { commodities }\end{array}$ & -0.1 & 0.1 & 0 & 0 & 0 & 0.0 \\
\hline $\begin{array}{l}\text { Nonagricultural } \\
\text { commodities }\end{array}$ & -0.8 & -0.3 & -1.0 & -0.4 & -0.7 & -0.7 \\
\hline $\begin{array}{l}\text { Short-run total } \\
\text { change in poverty } \\
\text { headcount }\end{array}$ & 0.7 & -0.5 & -2.8 & -0.9 & -0.6 & -0.3 \\
\hline $\begin{array}{l}\text { Long-run total change } \\
\text { in poverty headcount }\end{array}$ & -1.1 & -1.2 & -1.6 & -0.8 & -1.2 & -1.2 \\
\hline
\end{tabular}

Source: Authors' calculations based on Indonesia 1993 household survey and GTAP 5 data.

sharpest percent change $(-2.8$ percent) in the labor-specialized stratum (table 7$)$. The short-run poverty headcount among agriculture-specialized households increases as a result of trade liberalization. Agricultural profits rise by less than the increase in prices for staple grains and other food products due to the sharp increase in wages. Services prices also rise at a faster rate. However, the national impact of this slight increase in poverty among agriculture-specialized households is offset by declines in poverty in other strata. Consequently, national poverty falls 0.3 percent in the short run as a result of global trade liberalization.

Disaggregation by type of trade reform of the short-run poverty headcount impacts by stratum shows that different types of trade liberalization have different effects on poverty in the various strata (see table 7). Liberalization of Indonesia's own trade policies increases poverty in Indonesia. The commodity price declines following the tariff cuts are insufficient to offset declining incomes as Indonesia experiences the real depreciation required to restore external balance in the wake of increased imports.

The largest reductions in national poverty result from developed economy agricultural trade liberalization $(-0.5$ percent) and nonagricultural trade 
liberalization ( -0.7 percent). Liberalization of developed country trade lowers poverty among the agriculture-specialized and diversified households, which account for nearly 80 percent of the poor in Indonesia. Thus, these reductions in poverty determine the overall outcome, and national poverty falls despite the rise in poverty among other household groups. Liberalization of nonagricultural trade by developed economies lowers poverty in every group except the agriculture-specialized households. Thus, liberalization of nonagricultural trade by developed countries complements agricultural liberalization. Economywide trade liberalization, which results in broad-based reductions in poverty, is preferable to narrow sector-specific measures, which tend to benefit one group at the expense of others.

Liberalization of the agricultural trade policies of other developing economies does not affect the short-run national poverty rate in Indonesia because these trade policies have a negligible impact on prices in Indonesia (table 6). However, liberalization of developing economy nonagriculture trade reduces poverty across all strata in Indonesia because developing economy tariffs on manufactures are so high.

Long-Run Effects. The most striking thing about the long-run poverty headcount impacts is the greater degree of uniformity across strata (see table 7). Whereas the short-run impacts include both increases and reductions in poverty, with great variations in the extent of reductions (from -0.5 percent to -2.8 percent), the long-run impacts are relatively similar across all strata, with poverty rates falling by -1.1 percent and -1.6 percent in non-transferdependent households. This happens because once the imputed returns to selfemployed labor are accounted for, poor households are essentially reliant on unskilled wages (recall figures 5 and 6). If real unskilled wages rise, then poverty falls. This point is also emphasized in the analysis of Harrison and others (2002a) for Brazil.

\section{Impacts across the Income Distribution}

A more comprehensive analysis of the impacts of alternative trade liberalization measures on household welfare across the income spectrum involves computing the equivalent variation (Ev) of the ensuing price and income changes by solving equations 2-5 for the transfer required to give each household the postreform level of utility at prereform prices. This EV is subsequently normalized by initial income to show the percentage gain across the income spectrum. If this curve is rising, it indicates a regressive effect-that trade liberalization benefits the wealthy more than the poor-and if it is falling, it indicates a progressive effect, with greater benefits for the poor than for the rich.

The distribution of EV impacts across the income spectrum in Indonesia, under the short-run closure, is plotted for households in each stratum, arranged from poorest to richest, with a line connecting the households in each stratum (figure 8). For example, because the richest agriculture-specialized household is in the 87th percentile, the ev line for this stratum terminates there. The richest 
Figure 8. Equivalent Variation (Relative to Initial Income) due to Global Trade Liberalization, by Stratum

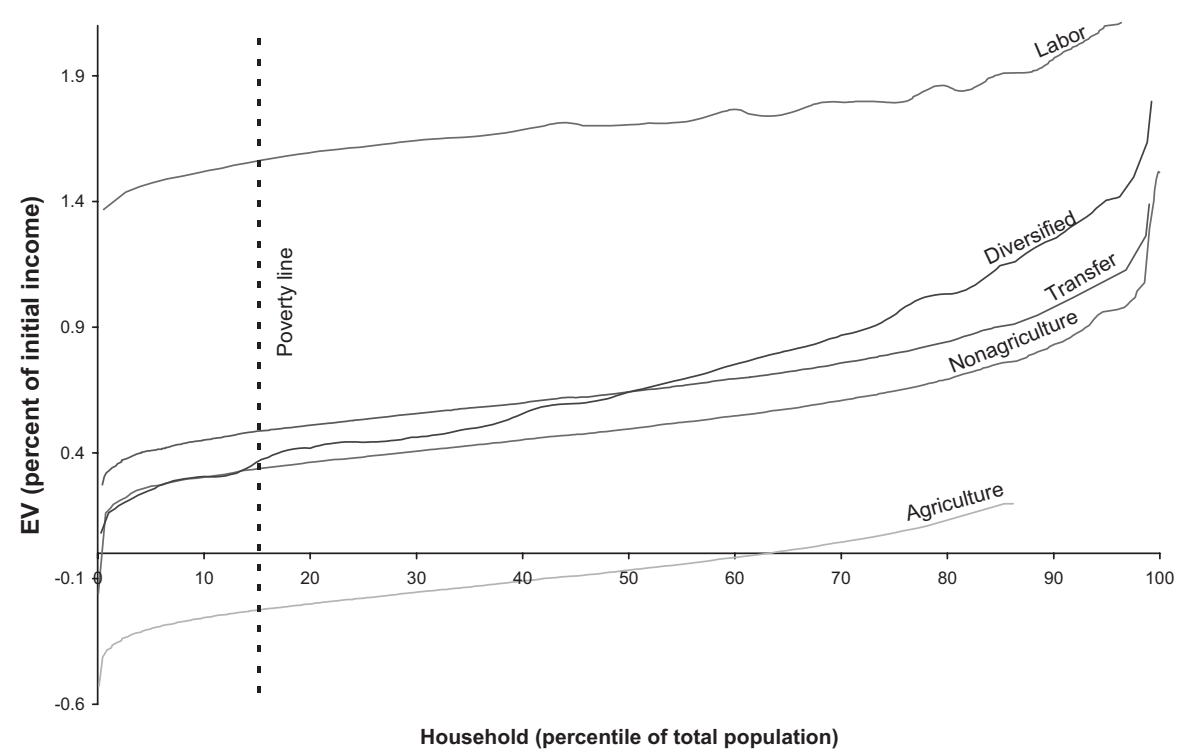

Source: Authors' calculations based on microsimulation model for Indonesian households.

households in the survey are in the nonagriculture-specialized stratum. The poverty line, based on the poverty headcount information reported in table 1 , is shown as the 15 th percentile.

There is a clear upward slope for all strata, indicating that the rich benefit more from trade liberalization than do the poor. As anticipated from the poverty results, the poor households in the agriculture-specialized stratum are hurt in the short run by global trade liberalization. Only the wealthiest households in this stratum gain. In contrast, the wage-specialized households benefit across the entire income spectrum as wages rise relative to commodity prices. Members of the other three strata also gain, though more modestly.

The EV curves all have the same shape (see figure 8 ). This shape is inherited from the consumption side of the story. Recall that the consumption parameters in the microsimulation model are independent of the stratum-all households in Indonesia have the same parameters. What distinguishes their consumption bundle (given common prices) is their per capita income and hence their utility level. Furthermore, based on the estimated parameters, household spending at the lowest income levels is dominated by staple grains and other food products, whereas at the highest income levels durable goods and services are more important.

At the lowest income levels the consumption component of the relative $\mathrm{EV}$ measure ("total" line in figure 9) amounts to about -4 percent of income. The bulk of this is due to higher prices for staple grains and other food products, 
Figure 9. Consumption Impacts (Relative to Initial Income) of Global Trade Liberalization, by Stratum

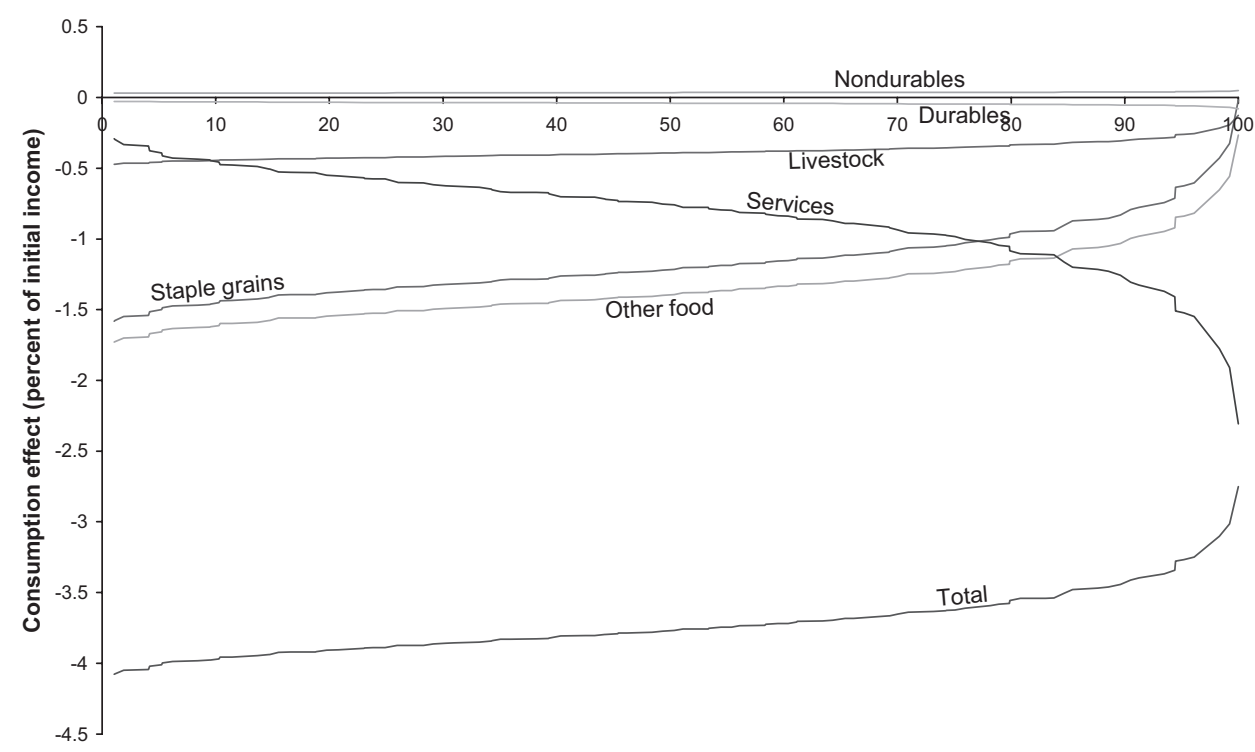

Household (percentile of total population)

Source: Authors' calculations based on microsimulation model for Indonesian households.

which experience the highest consumer price increases (5.4 percent for grains and 6.1 percent for other food products) and claim a large share of the poorest consumers' budgets. The relative contribution of these food price increases to the relative EV diminishes at higher income levels due to the smaller budget share devoted to these items (recall figure 7). The change in livestock price is more modest, as is its budget share in Indonesia, so its contribution to the consumption price EV is smaller. The prices of durables and nondurables change little under trade liberalization. The main nonfood price impact is in the services aggregate, which rises strongly due to the higher wages. The services impact on the consumption component of the relative $\mathrm{EV}$ is small at the lowest income levels because of its small share in consumers' budgets. However, the services impact is quite important at the highest income levels, where it dominates the total impact on wealthy consumers. Overall, the shape of the total consumption component of EV takes its cue from food prices, although their effect is offset somewhat by the increase in service prices.

For factor earnings' contributions to households' EV the short-run earnings story is nearly invariant across the income spectrum for specialized households. Thus the self-employed nonagriculture-specialized households' EV curve in figure 8 is essentially a parallel upward shift of the agriculture-specialized households' EV line, with the difference owing to the differential change in nonagricultural and agricultural profits. Similarly, the transfer-specialized 
households represent another incremental shift upward. The case is different for the diversified household EV curve, since these households fare less well than nonagricultural-specialized households at the lowest income levels (see figure 8), but gain much more at the highest income levels-even more than the wealthy transfer-specialized households. This suggests a change in the mix of diversified household income as per capita household earnings rise.

This issue is explored further by disaggregating the short-run income side of the relative EV results in figure 8 for the diversified household stratum. At lowincome levels agricultural profits contribute the most to the relative change in income (figure 10). However, this contribution declines steadily as income levels rise until it is superceded in importance just after the 50th percentile by the contribution of unskilled wages and nonagricultural profits. At the highest income level this component of the relative change in diversified household income has become nearly the least important one. Overall, the relative income change increases as the income percentile rises. This follows from the interaction between the relative importance of the different sources of earnings with their respective factor prices. As incomes in this stratum rise, earnings shift toward factors that are more favorably affected by trade liberalization.

Finally, the change in mix of contributing factors to the wage-specialized households' short-run, relative earnings changes is explored (figure 11). Because these households have a blend of skilled and unskilled labor, it is not surprising

Figure 10. Composition of Earnings Price Effects within the Diversified Stratum

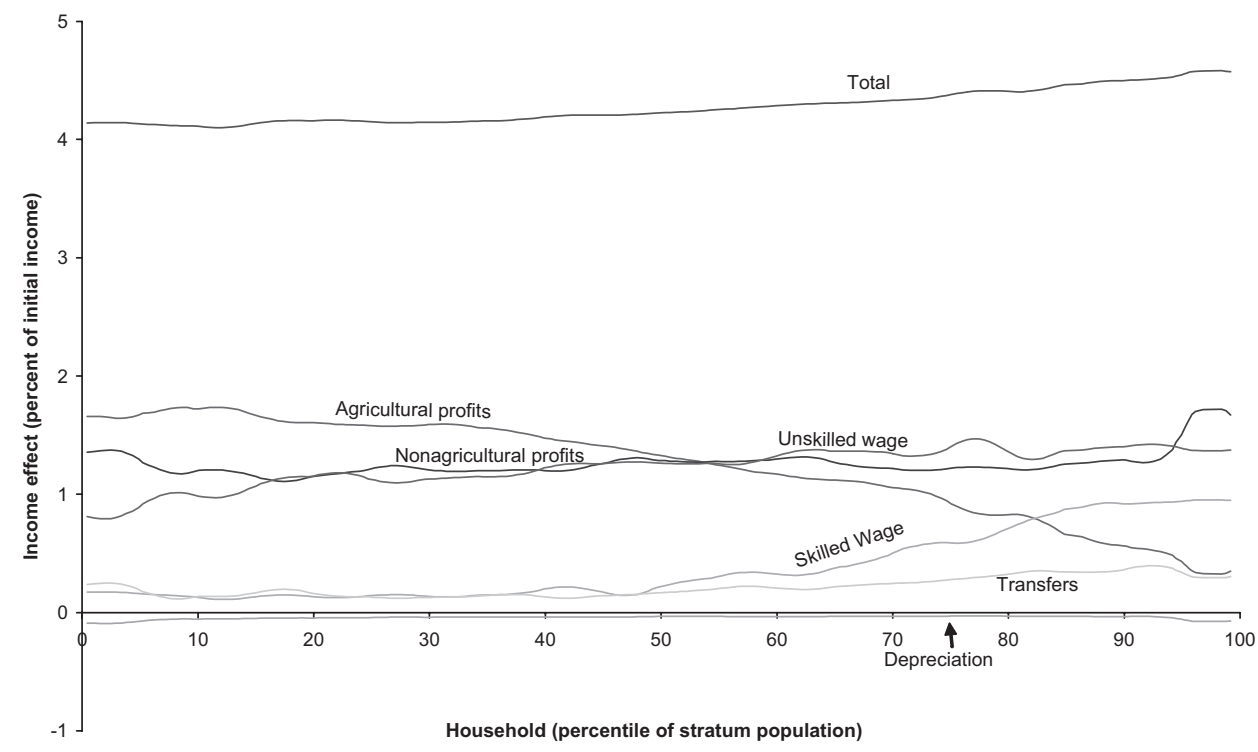

Source: Authors' calculations based on microsimulation model for Indonesian households. 
Figure 11. Composition of the Earnings Price Effects within the Wage-Specialized Stratum

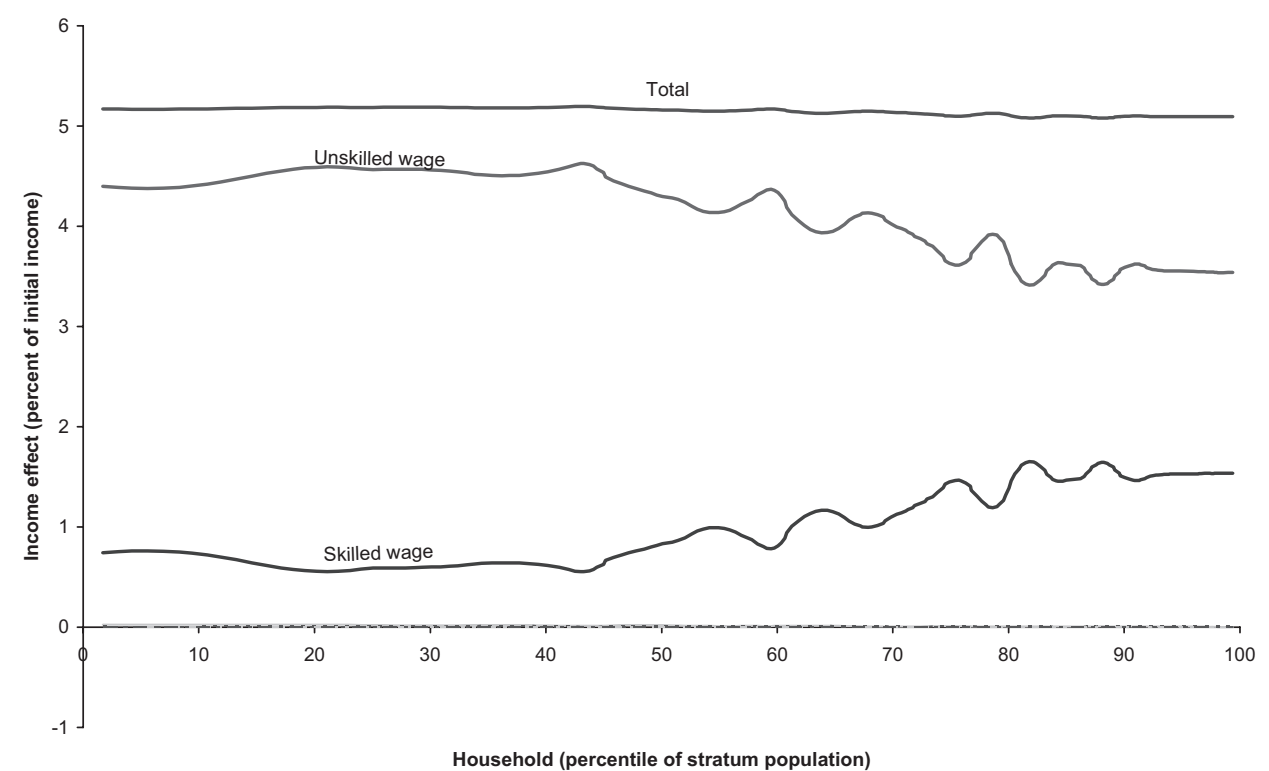

Source: Authors' calculations based on microsimulation model for Indonesian households.

to see that the relative importance of skilled labor rises with incomes. Because unskilled wages rise slightly more than skilled wages, the total earnings curve slopes slightly downward. This, in turn, explains why the total EV curve for the wage-specialized households in figure 8 loses some of its dominance over the transfer- and nonagricultural-specialized household strata as incomes rise.

\section{Conclusions}

Assessing the impact of multilateral trade liberalization on poverty is challenging. As Winters (2000, p. 43) notes: "Tracing the links between trade and poverty is going to be a detailed and frustrating task, for much of what one wishes to know is just unknown. It will also become obvious that most of the links are very case specific." Winters lays out a general framework for thinking about the impact of trade policy on poverty. This study is similar in spirit to Winters's effort. It recognizes that the definitive assessment of the impact of trade liberalization on poverty must be done on a case-by-case basis. It also recognizes the need for a set of internationally comparable estimates of the global impact on poverty in a range of different countries and develops a tractable methodology for providing this. The approach relies on detailed earnings data from household surveys; an econometrically estimated demand system 
that reflects the changes in consumption patterns across the income spectrum and that provides a natural vehicle for analysis of household welfare and poverty, particularly in the context of multicountry analyses; and a micromacro consistent framework for projecting the price impacts of global trade liberalization.

The approach is applied to an assessment of the consequences of global liberalization of merchandise tariffs, agricultural export subsidies, and quotas on textiles and clothing. To fully develop the analysis, the study focuses on the consequences for Indonesia. The approach could readily be applied to any of the other 13 countries for which microconsistent databases have been assembled. For Indonesia the national headcount measure of poverty is reduced following global trade liberalization in both the short and the long run.

However, the aggregate reduction in Indonesia's national poverty headcount masks a more complex set of impacts across different strata. In the short run the poverty headcount rises slightly for self-employed, agriculture-specialized households, as the rise in farm profits is outpaced by consumer prices. Therefore, this study echoes Kanbur's (2000) call for disaggregated analyses of poverty impacts. In the long run, however, the poverty headcount in Indonesia falls for all strata, because the increased demand for unskilled workers lifts incomes for the formerly self-employed, some of whom move into the wage labor market.

The study also decomposes the change in headcount poverty in Indonesia associated with different countries' trade policies. Liberalization of other countries' trade policies leads to a reduction in the national poverty headcount in Indonesia. Liberalization of Indonesia's own trade policies-particularly those protecting the nonagricultural sectors-leads to an increase in national poverty.

In summary, the framework developed here fills an important gap in researchers' toolkits for analysis of the poverty impacts of multilateral trade liberalization. By stratifying households according to earnings specialization, it captures a great deal of the diversity relevant to trade policy impacts while preserving analytical tractability and comparability across countries. Another important contribution of this work is to show how consumer spending across the income spectrum can be characterized using a single, econometrically estimated demand system. Once calibrated to match observed national spending patterns, this demand system yields a unique poverty level of utility that provides an ideal benchmark for evaluating changes in poverty rates using any member of the class of poverty measures proposed by Foster and others (1984). Although this approach is illustrated by an analysis of the poverty impacts of trade liberalization in Indonesia, it can be applied to other countries. This approach should enrich traditional analyses of multiregion trade liberalization, making them more relevant for policymakers who are increasingly concerned about the consequences of such actions for poverty in developing economies. 


\section{REFERENCES}

Adelman, Irma, and Sherman Robinson. 1978. Income Distribution Policy: A Computable General Equilibrium Model of South Korea. Stanford: Stanford University Press.

Atkinson, A. B., L. Rainwater, and T. M. Smeeding. 1995. Income Distribution in OECD Countries. Paris: OECD.

Biro Pusat Statistik. 1993. “susenas: Indonesia’s Socio-Economic Survey.” Jakarta, Indonesia.

Bourguignon, François, and Pierre Andre Chiappori. 1994. "Income and Outcomes: A Structural Model of Intra-Household Allocation." In The Measurement of Household Welfare, ed. R. Blundell, I. Preston, and I. Walker. Cambridge: Cambridge University Press.

Bourguignon, François, Anne-Sophie Robilliard, and Sherman Robinson. 2002. "Representative vs. Real Households in the Macro-economic Modeling of Inequality." Paper prepared for the Conference on Frontiers in Applied General Equilibrium Modeling, Yale University, April 5-6, New Haven, Conn.

Case, Anne. 1998. "Income Distribution and Expenditure Patterns in South Africa." Paper prepared for the Conference on Poverty and the International Economy organized by World Bank and Swedish Parliamentary Commission on Global Development, October 20-21, 2000, Stockholm.

Chen, Shaohua, and Martin Ravallion. 2003. "Welfare Impacts of China's Accession to the World Trade Organization.” World Bank Economic Review 18(1):29-57.

Chen, S., and Y. Wang. 2001. "China's Growth and Poverty Reduction: Trends between 1990 and 1999.” Policy Research Working Paper 2651. World Bank, Washington D.C.

Cline, W. 2004. Trade Policy and Global Poverty. Washington, D.C.: Institute for International Economics.

Cogneau, Denis, and Anne-Sophie Robillard. 2000. "Growth, Distribution and Poverty in Madagascar: Learning from a Microsimulation Model in a General Equilibrium Framework.” Discussion Paper 61. International Food Policy Research Institute, Trade and Macroeconomics Division, Washington, D.C.

Cranfield, J. A. L. 1999. "Aggregating Non-Linear Consumer Demands-A Maximum Entropy Approach.” Ph.D. diss., Purdue University, Department of Agricultural Economics, West Lafayette, Ind.

Cranfield, John A. L., Thomas W. Hertel, and Paul V. Preckel. 2000. "Multi-lateral Trade Liberalization and Poverty." Paper prepared for the Conference on Poverty and the International Economy organized by World Bank and Swedish Parliamentary Commission on Global Development, October 20-21, Stockholm.

Cranfield, J. A. L., J. S. Eales, T. W. Hertel, and P. V. Preckel. 2003. "Model Selection When Estimating and Predicting Consumer Demands Using International, Cross Section Data." Empirical Economics 28(2):353-64.

Cranfield, J. A. L., P. V. Preckel, J. S. Eales, and T. W. Hertel. 2002. "Estimating Consumer Demand across the Development Spectrum: Maximum Likelihood Estimates of an Implicit Direct Additivity Model." Journal of Development Economics 68(2):289-307.

2004. "Simultaneous Estimation of an Implicit Directly Additive Demand System and the Distribution of Expenditure-An Application of Maximum Entropy.” Economic Modelling 21: 361-85.

Decaluwé, B., A. Patry, L. Savard, and E. Thorbecke. 1999. "Poverty Analysis within a General Equilibrium Framework.” Working Paper 99-06. Université Laval, Départment d'économique, Centre de Recherche en Économie et Finance Appliquées, Quebec, Canada.

Deininger, K., and L. Squire. 1996. "A New Data Set Measuring Income Inequality." World Bank Economic Review 10(3):565-91.

Devarajan, Shantayanan, and Dominque van der Mensbrugghe. 2000. "Trade Reform in South Africa: Impacts on Households." Paper prepared for the Conference on Poverty and the International Economy organized by World Bank and Swedish Parliamentary Commission on Global Development, October 20-21, Stockholm. 
Dimaranan, Betina V., and Robert A. McDougall. 2002. Global Trade, Assistance, and Protection: The gtap 5 Data Base. West Lafayette, Ind.: Purdue University, Department of Agricultural Economics, Center for Global Trade Analysis.

Evans, David. 2001. "Identifying Winners and Losers in Southern Africa from Global Trade Policy Reform: Integrating Findings from GTAP and Poverty Case Studies for a Zambian Example.” Paper prepared for the Economics and Social Research Council Development Economics/International Economics Conference, Nottingham University, April 5-7, Nottingham, UK.

Foster, J. E., J. Greer, and E. Thorbecke. 1984. "A Class of Decomposable Poverty Measures.” Econometrica 52(3):761-66.

Friedman, Jed. 2001. "Differential Impacts of Trade Liberalization on Indonesia's Poor and Non-Poor.” Paper prepared for the Conference on Poverty and the International Economy organized by World Bank and Swedish Parliamentary Commission on Global Development, October 20-21, Stockholm.

Gibson, P., J. Wainio, and D. Whitley. 2002. "Agricultural Tariff Data.” In Global Trade, Assistance, and Protection: The GTAP 5 Data Base, ed. Betina V. Dimaranan and Robert A. McDougall. West Lafayette, Ind.: Purdue University, Department of Agricultural Economics, Center for Global Trade Analysis.

Haddad, L., and R. Kanbur. 1990. "How Serious is the Neglect of Intra-household Inequality?" Economic Journal 100(402):866-81.

Harrison, Glen W., Thomas F. Rutherford, and David G. Tarr. 2002a. "Regional, Multilateral and Unilateral Trade Policies of MERcosur for Growth and Poverty Reduction in Brazil.” Working Paper 3051. World Bank, Washington, D.C.

- 2002b. "Trade Liberalization, Poverty and Efficient Equity." Paper prepared for the Conference on Poverty and the International Economy organized by World Bank and Swedish Parliamentary Commission on Global Development, October 20-21, 2000, Stockholm. Also published in 2003 Journal of Development Economics 71:97-128.

Harrison, W. Jill, J. Mark Horridge, and K. R. Pearson. 1999. "Decomposing Simulation Results with Respect to Exogenous Shocks.” Paper presented at the Second Annual Conference on Global Economic Analysis, June 20-22, Copenhagen.

Hertel, Thomas W., ed. 1997. Global Trade Analysis: Modeling and Applications. New York: Cambridge University Press.

Hertel, Thomas W., Paul V. Preckel, and John A. Cranfield, 2000. "Multilateral Trade Liberalization and Poverty Reduction.” Paper prepared for the Conference on Poverty and the International Economy organized by World Bank and Swedish Parliamentary Commission on Global Development, October 20-21, Stockholm.

Ianchovichina, Elena, Alessandro Nicita, and Isidro Soloaga. 2000. "Implications of Trade Reform on the Distribution of Income in Mexico.” Paper prepared for the Conference on Poverty and the International Economy organized by World Bank and Swedish Parliamentary Commission on Global Development, October 20-21, Stockholm.

- 2002. "Trade Reform and Poverty: The Case of Mexico." World Economy 25(7):945-73.

Ivanic, Maros. 2003. "Reconciliation of the GTAP and Household Survey Data on Factor Earnings." GTAP Research Memorandum \#5. Purdue University, Department of Agricultural Economics, Center for Global Trade Analysis, West Lafayette, Ind. Available online at www.gtap.agecon.purdue.edu/ resources/res_display.asp? recordidD=1408.

Kanbur, R. 2000. "Income Distribution and Development.” In Handbook of Income Distribution, ed. A. B. Atkinson and F. Bourguignon. Amsterdam: Elsevier.

Kravis, I. B., A. W. Heston, and R. Summers. 1982. World Product and Income: International Comparisons of Real Gross Product. Baltimore: Johns Hopkins University Press.

Levinsohn, James, Steven Berry, and Jed Friedman. 1999. "Impacts of the Indonesian Economic Crisis: Price Changes and the Poor." Paper prepared for the Conference on Poverty and the International Economy organized by World Bank and Swedish Parliamentary Commission on Global Development, October 20-21, Stockholm. 
Lipton, M., and M. Ravallion. 1995. "Poverty and Policy." In Handbook of Development Economics, ed. J. Behrman and T. N. Srinivasan. Amsterdam: Elsevier.

Löfgren, Hans. 1999. "Trade Reform and the Poor in Morocco: A Rural-Urban General Equilibrium Analysis of Reduced Protection.” Discussion Paper 38. International Food Policy Research Institute, Trade and Macroeconomics Division, Washington, D.C.

McCulloch, N., L. A. Winters, and X. Cirera. 2001. Trade Liberalization and Poverty: A Handbook. London: Center for Economic Policy Research.

Mistiaen, J., and M. Ravallion. 2003. "Survey Compliance and Distribution of Income." Policy Research Working Paper 2956. World Bank, Washington, D.C.

Reimer, Jeffrey J. "Estimating the Poverty Impacts of Trade Liberalization.” Policy Research Working Paper 2790. World Bank, Washington, D.C.

Rimmer, M. T., and A. A. Powell. 1992a. "Demand Patterns across the Development Spectrum: Estimates of AIDADS.” Working Paper OP-75. Monash University, Centre of Policy Studies, Clayton, Victoria, Australia.

—. 1992b. "An Implicitly Directly Additive Demand System: Estimates for Australia." Working Paper OP-73. Monash University, Centre of Policy Studies, Clayton, Victoria, Australia.

- 1996. “An Implicitly Additive Demand System.” Applied Economics 28(12):1613-22.

Winters, L. Alan. 2000. “Trade, Trade Policy, and Poverty: What Are the Links?” Discussion Paper 2382. Centre for Economic Policy Research, London.

Winters, L. A., N. McCulloch, and A. McKay. 2003. "Trade Liberalisation and Poverty: The Empirical Evidence." Discussion Paper 88. University of Sussex, Institute of Development Studies, Falmer, Brighton, UK.

World Bank. 1992. World Development Report 1992: Development and the Environment. New York: Oxford University Press. Press.

- 1993. World Development Report 1993: Investing in Health. New York: Oxford University

. 2000. World Development Report 2000/2001: Attacking Poverty. Oxford: Oxford University Press. 